\title{
Metacognition researches in Turkey, Japan and Singapore
}

\author{
Ayşe Elitok Kesici ${ }^{1}$, Derya Güvercin², Hızır Küçükakça ${ }^{3}$ \\ ${ }^{1}$ Department of Curriculum and Instruction, School of Education, Aydın Adnan Menderes University, Turkey \\ ${ }^{2}$ Çorlu District National Education Directorate, Turkey \\ ${ }^{3}$ Aydın District National Education Directorate, Turkey
}

\begin{tabular}{l} 
Article Info \\
\hline Article history: \\
Received Sep 9, 2020 \\
Revised Mar 15, 2021 \\
Accepted Apr 12, 2021 \\
\hline
\end{tabular}

\section{Keywords:}

Comparative education

Japan

Metacognition

Singapore

Turkey

\begin{abstract}
In this study, fundamental researches on "metacognition" in Turkey, Japan and Singapore between the years of 2010 and 2020 were examined and conclusions were made in terms of comparative education. For this purpose, the data of the research was collected by document scanning method and the data were analyzed using the document review technique, which is one of the qualitative research method techniques. Years of studies, countries, objectives, research methods, sample working group, data analysis methods and results; it has been examined according to comparative education approaches and data collection techniques. As a result, quantitative research methods are seen to be frequently used in researches on metacognition in these three countries. It has been determined that experimental studies are the main research patterns of the metacognition studies conducted in three countries. Metacognitive awareness scales are the most used data collection tools in all three countries. Considered in general; the research made about metacognition in Singapore Turkey and Japan shows that the studies investigating the relationship between students' problem-solving skills and metacognition are in majority. Researches examining the relationship between metacognition and foreign language teaching are also widely discussed.
\end{abstract}

This is an open access article under the CC BY-SA license.

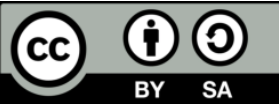

\section{Corresponding Author:}

\section{Ayşe Elitok Kesici}

Department of Curriculum and Instruction, School of Education

Aydın Adnan Menderes University

Zafer, 09010 Efeler/Aydın, Turkey

Email: aelitok@adu.edu.tr

\section{INTRODUCTION}

Mankind has been in a process of development since its existence. It owes this development to thinking, which is the most basic ability that distinguishes humans from other creatures and enables human development as an entity. Metacognition is an integral part of the ability to think. The concept of metacognition has been gaining importance day by day and has become one of the most mentioned concepts especially in the field of education in recent years. Metacognition emphasizes an important conceptual framework that affects students' learning in school settings. If metacognitive awareness can be developed in learners, the quality of individuals' learning may also increase.

Expressed in English as "metacognition", this metacognition concept appears in various forms such as "metacognition", "executive cognition", "metacognition" and "cognition of cognition" in the literature [1]. Since the emergence of the metacognition concept, many definitions have been made. The concept of metacognition in the field of education was first used in an article by Flavell [2]. Flavell used the term metamemory for the first time in a study on children's advanced memory abilities and included this concept in the literature. Later, Flavell [3] explained metacognition as; it expresses the individual's knowledge of cognitive 
processes and outcomes, or anything related to them. Brown [4] defines metacognition as students' thinking in detail about their cognitive skills and self-regulation during learning. Nelson [5] assess metacognition as "a special type of cognition" and defines it as "cognitions of the individual about his own cognitions".

Schraw and Dennison [6] state that metacognition means the ability of the individual to reflect, grasp and manage his own learning in detail. Metacognition can generally be defined as "cognition about cognition" or "thinking about thinking" and includes metacognitive information that controls knowledge of human cognitive activities and metacognitive activities [4], [7]-[9].

Methods to make schools suitable for students include; increasing communication between students, providing opportunities for students to choose activities in line with their interests, providing collaboration between teachers, staff and students, creating opportunities for students to use their skills and knowledge, and developing harmony between staff and the organization's objectives [10]. In order to provide learning environments with these features, the metacognitive features of individuals should also be taken into consideration.

Considering the studies on metacognition, it is possible to reach many studies examining the variables that affect metacognition and metacognitive awareness. In literature, there are many studies showing the relationship between intelligence and metacognition, the effects of teaching methods on metacognitive awareness, the relationship between language learning and metacognition, the effects of problem solving and establishment skills on metacognition, effects of reading comprehension on metacognitive awareness, academic success, social skills, concept learning and thinking out loud technique [11]-[19]. Research addresses various variables and processes to which this concept is associated to better explain metacognition. Mok and Flynn [20] conceptualized the classroom environment on three fundamentals, the first of which is the academic atmosphere of the class, the second is the atmosphere of personal relations, and the last one is the class discipline. Especially, the relationship between metacognition and academic achievement is an important factor in the acquisition process of the learners. Countries wishing to be successful in international examinations should be sensitive to the issue of metacognitive and metacognitive awareness. Because Turkey's success in international exams is low in general, more metacognitive studies are needed to be done in order to enhance academic achievement.

The absence of a comparative study among the countries in the literature makes this research important. Comparative education is a discipline that helps to identify similarities and differences of two or more education systems in different cultures and different countries, explains similar-looking phenomena and offers useful proposals about ways to educate people [21]. Comparative education is an area that examines educational phenomena, examines cultural, economic, political and social relations, and aims to solve educational problems [22]. Comparative education is a complex field of study which helps to understand education and it is closely related to disciplines such as psychology, linguistics, economics, sociology, history, and anthropology [23]. Comparative education was chosen as an approach in this study because of its relation to different concepts such as thinking types, problem solving and establishing skills, teaching methods and techniques, in other words, forming the basis of different disciplines. With these features, metacognition has a feature that directly affects learning processes. With metacognitive awareness, individuals will become more conscious learners [24].

In this study, Turkey, Singapore and Japan were compared in the study of metacognition. Another reason why a comparison of metacognition research among the three countries was applied is that Singapore and Japan are always at the top in the international Programme for International Student Assessment (PISA) examination and Turkey always finds a place at a much lower position. When we look at the overall average of PISA exam success in 2018; Singapore has the second place, Japan is in the sixth place and Turkey has the fortieth rank among the total of 77 countries [25]. Similarities and differences between these countries will be examined and a due diligence will be made through metacognition research. In this research, comparisons will be made in order to set an example for education systems of developing countries.

Thinking is a complex process that starts from the birth of human beings until the death and takes place consciously or unconsciously. This process is the sole basis for the development of individuals. Metacognition, on the other hand, means that the individual is aware of his own thinking process and can develop an autocontrol about this process. Metacognition is seen as an important concept for the development of individuals and a wide range of research is done in this area. However, the researches did not emphasize the comparison of metacognition studies among different countries. The aim of this study was to compare the metacognition research in Turkey, Singapore and Japan between the years of 2010 and 2020. For this purpose, the research problem can be stated as "What are the features of metacognition research in Turkey, Singapore and Japan?" The years, countries, research methods, sample working group, data analysis methods and results of the researches were examined according to comparative education approaches and data collection techniques. Via these comparisons, the effects of metacognitive awareness in Singapore and Japan educational systems are expected to be spotted and lead as a source for Turkish national education system. So that it will 
contribute to increase Turkish students' success in international exams such as PISA, Trends in International Mathematics and Science Study (TIMSS) and Progress in International Reading Literacy Study (PIRLS).

\section{RESEARCH METHOD}

Bray and Thomas method, one of the methods used in comparative education, was used in the research. Bray and Thomas [26] have developed a method that can be used to classify comparative studies in education by level and type. The method, which can be considered as a breakdown of the topics examined in comparisons, is an analytical tool for the comparative study of who, what and where questions of research [27]. In response to the question "who" Turkey, Japan and Singapore were selected as countires, in response to the question "what" metacognition and in response to the question "where" document analysis environment were defined. In this research, "review" method was used to examine metacognition studies. In this method, written documents about the phenomenon or events discussed in the research are analyzed [28]. Literature reviews are used to guide future research and practices by revealing important links and forms in field research in educational research [29]. In this context, relevant articles and theses were scanned and data were obtained. During the research, while analyzing the documents, the current databases were examined and primary sources were tried to be reached, and the databases of the education ministries of the relevant countries, virtual libraries, websites of the universities and databases of scientific publications were used.

In the study, the keywords used when investigating the metacognition concept in the related countries were determined as "metacognition" and "metacognitive". Content analysis of the resources reached in line with these keywords was made. Suri and Clarke [30] define the importance of content analysis as "research syntheses that have a valuable role in shaping future studies, practices, policies and disseminating the research topic". In order to collect data in the study, the search was done by entering the keyword "metacognition" in the databases such as "Researchgate," "Academia," "ERIC" and YOK Thesis Center and then in the Google Scholar search engine. Full text articles were reached as a result of this search. In addition, various theses on the subject have been used. In this study, 14 full text journal articles were accessed and one thesis was examined. In this context, 52 sources have been reached. Scans, according to Karasar [31]; are research approaches that try to describe a situation as it is in the past or still. In this study, secondary data sources published in the past related to metacognition were investigated. Therefore, the study is in the literature review model. According to Erkuş [32] literature reviews are to examine and analyze the works that have been done and accumulated in a certain area. In this method, the advantages and disadvantages of the studies are critically handled and important inferences are made for new studies.

In this working process a three-step method [33]:

1) Determination of the survey method and selection criteria: Quantitative, qualitative and mixed method researches were examined in order to clearly determine the characteristics and results of the studies and metacognition research. It was taken into consideration that they were published in refereed journals using these research patterns.

2) Scanning process: In this stage, firstly, queries with keywords were conducted in databases.

3) Analysis process: The way in which articles and theses deal with the concept of metacognition, the years of studies, research methods, sample study groups, data analysis methods and the results reached in the researches were examined. Findings have emerged within this framework.

\section{FINDINGS}

In this part of the research, as a result of the literature review, general analysis of the studies has been done by including studies about metacognition made in the relevant countries. In Table 1, four research articles from Turkey and five research articles selected respectively from Japan and Singapore are demonstrated. These articles are fourteen in total. In addition, in Table 1, there is one thesis from Turkey. The countries, researchers, years and names of the theses and articles are included in the Table 1. 
Table 1. Studies about metacognition in Turkey, Japan and Singapore

\begin{tabular}{|c|c|c|}
\hline Country & Reference & Research title \\
\hline \multirow[t]{5}{*}{ Turkey } & [1] & The effect of web based education on learners' awareness of metacognition \\
\hline & [34] & Relationship among metacognition, intelligence and learning performance from text \\
\hline & [35] & Metacognitive awareness of reading strategies levels of secondary school students \\
\hline & [36] & $\begin{array}{l}\text { Examining metacognitive awareness of prospective secondary school mathematics } \\
\text { teachers in terms of some variables }\end{array}$ \\
\hline & [37] & $\begin{array}{l}\text { An investigation of the levels of English teacher candidates using metacognitive } \\
\text { reading strategies in terms of different variables (The case of Erciyes University) }\end{array}$ \\
\hline \multirow[t]{5}{*}{ Japan } & [38] & $\begin{array}{l}\text { The effects of a study abroad experience on the L2 motivational self and } \\
\text { metacognitive skills: A study of a junior high school trip abroad }\end{array}$ \\
\hline & [39] & $\begin{array}{l}\text { A quantitative survey on metacognitive awareness of reading strategy use in English } \\
\text { by Japanese university students }\end{array}$ \\
\hline & [40] & $\begin{array}{l}\text { Promoting cognitive and metacognitive awareness through self-study modules: An } \\
\text { investigation into advisor comments }\end{array}$ \\
\hline & [41] & Development of critical thinking with metacognitive regulation \\
\hline & [42] & $\begin{array}{l}\text { Self-Access and Metacognitive Awareness in Young Learners: How Japanese sixth } \\
\text { graders learn how to learn English }\end{array}$ \\
\hline \multirow[t]{5}{*}{ Singapore } & [43] & The impact of metacognitive scaffolding and monitoring on reading comprehension \\
\hline & [44] & Partial metacognitive blindness in collaborative problem solving \\
\hline & [45] & $\begin{array}{l}\text { A metacognitive approach in kick-starting the understanding and planning phases of } \\
\text { mathematical problem solving }\end{array}$ \\
\hline & [46] & Shifting pre-service teachers' metacognition through problem solving \\
\hline & [47] & $\begin{array}{l}\text { Influences of metacognitive and self-regulated learning strategies for reading on } \\
\text { mathematical literacy of adolescents in Australia and Singapore }\end{array}$ \\
\hline
\end{tabular}

\subsection{Findings about research on metacognition in Turkey}

Saraç, Önder and Karakelle [34] studied about the relationship between metacognitive information, metacognitive monitoring and metacognitive control, general intelligence and text learning performance. The research was created by quantitative method. The research sample consists of 91 primary school fifth grade students from five different public schools in the city center, whose families belong to middle income level. In order to measure general intelligence; Raven Progressive Matrices Test, in order to measure students' metacognitive knowledge levels; the Metacognitive Awareness Scale Form A (UBFÖ-Ç) developed by Sperling, et al. [48] for third, fourth, and fifth grade students, for the purpose of measuring students' metacognitive supervision levels were used and regression analysis was implemented to analyze the data collected by using thinking aloud protocols. Regression analysis results suggest that metacognitive information does not contribute to variability in text learning performance, while metacognitive monitoring and metacognitive supervision contribute significantly to variation in text learning performance along with general intelligence. As a result of the research, it was observed that there was no significant relationship between metacognitive information and metacognitive control and general intelligence, while there was a statistically significant relationship between metacognitive monitoring and general intelligence.

The purpose of Baltaci and Akpinar [1] research is to determine the effect of web-based education on students' metacognitive awareness level. The research was created by quantitative method. The research was carried out on a total of 86 (43 experiments, 43 control) students studying at the Vali Ahmet Cemil Serhadlı Primary School, located in the city center of Diyarbakır in the 2008-2009 academic year. In this study carried out by experimental method, the model with pretest-posttest control group was used. The data in the study were obtained with the "Metacognition Awareness Inventory" developed by Schraw and Dennison [49]. In this study, which is based on the model with pretest-posttest control group in the analysis of the data, in comparison of the metacognitive awareness inventory scores of the students in the experimental and control groups independent groups "T" test (Independent Samples " $T$ " test); in comparison of the metacognitive awareness inventory scores of the groups, dependent groups ' $t$ ' test (Paired Samples t test) was used. It was determined from the analysis of the data that web-based teaching did not have a statistically significant effect on students' metacognitive awareness level.

The purpose of the research conducted by Kana [35] is to determine the metacognitive awareness levels of middle school students 'reading strategies, and to determine the relationship between students' metacognitive reading strategy usage levels and their reading levels, age, gender, book reading, Turkish reading level. The research was designed by quantitative method. Descriptive survey model was used in the research. The sample group of the research was created by random sampling method. The sample of the study consists of 350 th and 6th grade students studying in Istanbul in the first semester of the 2012-2013 academic year. In line with the aim of the research, Metacognitive Awareness of Reading Strategies Inventory adapted to Turkish by Öztürk [50] were applied to the students. T-test, regression and ANOVA analyzes were performed on the data obtained from the research with SPSS 20 statistics program. According to the findings obtained from the 
research, significant correlations were found between the students' use of metacognitive strategy and variables such as age, gender, reading, course success, and family reading level.

The aim of the research conducted by Deniz, et al. [36] is to examine the pre-service mathematics teacher candidates' awareness of using metacognition strategies and metacognitive dimensions; the knowledge of the cognition and designing of cognition dimensions according to their grade levels and gender. The research was created by quantitative method. The sample of the research consists of 117 prospective teachers studying at the Department of Secondary Mathematics Teaching at Erzurum Ataturk University Kazım Karabekir Education Faculty. Likert-type Metacognitive Awareness Inventory consisting of 52 items was used as a data collection tool in this study, which used a comparison method from the non-experimental designs of the quantitative approach. Two-way ANOVA and two-way MANOVA tests were performed by using SPSS 18.0 package program to analyze the data. According to the findings, there is no significant difference between metacognition awareness scores and grade levels and gender differences. In addition, there was no significant difference between the knowledge of cognition and cognition regulation scores.

The research by Gökşen [37] examined English teacher candidates' metacognitive reading strategies usage levels within the framework of different variables. The research was designed by quantitative method. Survey model was used in the research. The universe of the research was composed of English Language and Literature students of Erciyes University Faculty of Education and Faculty of Literature. The sample of the study consisted of 328 students, of which 217 were women and 111 were men. The Metacognitive Reading Strategies Questionnaire (MRSQ, Metacognitive Reading Strategies Questionnaire) developed by Taraban, Kerr and Rynearson [51] and adapted to Turkish by Cogmen [52] was used as the data collection tool. According to the results of the research, prospective English teachers use analytical and pragmatic strategies at the intermediate level. There was also no significant difference between the gender and the use of pragmatic strategy, which is one of the top metacognitive reading strategies, and it was seen that the level of female students using analytical strategies, which is another top metacognitive reading strategies was lower than male students. In addition, students whose mother education level is university graduate and students who have graduated from high school type "Science" and "Anatolian High School" use more metacognitive reading strategies.

\subsection{Findings about research on metacognition in Japan}

In his study, Adrian [38] investigated the effects of the second language (English) on students' motivational self and metacognitive skills. The sample of the study consists of 74 Japanese secondary school students participating in a short-term trip abroad. The mixed method was used in the research. A questionnaire form was used to collect data and observations were made. As a result of the research; a slight increase in students' motivation and metacognitive skills was observed immediately after their travel abroad. It was observed that students' motivations and metacognitive skills returned to their previous levels approximately two months after returning from travel. Based on the qualitative data obtained from students' responses to openended items in the questionnaires, the study program abroad is considered to be beneficial for the participants in the short term. More concern should be given to the study abroad program in order to achieve maximum effect of such experience.

In his study, Shikano [39] investigated the effect of the use of reading strategy in students' English class on their metacognitive awareness. The research was designed by quantitative method. 60 Japanese university students participated in the research. As a means of collecting data, Metacognitive Awareness Inventory was used to determine students' reading strategies. Factor analysis was performed to analyze the data obtained from the inventory. As a result of the research, it was concluded that the use of reading strategy in English lessons does not have a significant effect on students' metacognitive awareness. Therefore, the results of previous studies on this subject have been accepted. It is suggested that this study be done by choosing larger sample groups.

The research by Mynard [40] aims to analyze the comments of learning consultants to raise a deeper level of awareness about the individualized foreign language learning process and to promote metacognitive awareness. The research was designed by qualitative method. Seven student advisors participated in the study to obtain data from 24 university students. The data were collected during an education period using the oral and written interview method with the students' advisors. The data were subjected to content analysis and more than 2000 items were coded. As a result of the research, six themes related to metacognitive awareness were created in the process of individualized foreign language learning, based on the comments of consultants. These six themes were; in-depth research, interpretation, participation, counseling, communication and training. The researcher believes that the information obtained will guide future studies on metacognitive awareness.

The purpose of Gotoh's [41] research is to investigate the effect of metacognitive regulation and problem solving on the development of critical thinking. The research was designed by mixed method. There are 24 university students formed the sample group of the research. For research data, critical thinking rubric 
was applied to the students, and an interview about self-evaluation was conducted. Dependent sample T-test and content analysis were used to analyze the data. As a result of the research, it was concluded that metacognitive regulation and problem-solving process developed critical thinking. The researcher stated that the self-assessment form he used was not objective, so it might be wrong to comment only on this.

Werner and Kobayashi [42] examined individual learning and metacognitive awareness through how students learned English. The research was created by qualitative method. The sample of the study consisted of 34 primary school 6th grade students (11-12 years old). Research data were collected via semi-structured interview forms and in-class observation form. The data obtained in the research were analyzed using descriptive analysis technique. As a result, it has been observed that the cognitive and metacognitive awareness of students' English learning processes has increased. Researchers think that if a student's metacognitive awareness of learning increases, their success will increase not only in school but also outside school. Researchers suggest more studies to be done on individual learning.

\subsection{Findings about research on metacognition in Singapore}

Dabarera, Renandya and Zhang [43] examined the effect of using metacognitive strategy on reading comprehension in a foreign language. The research was created in a mixed method. Researchers designed their studies in an experimental design. The research sample consists of two study groups, the experimental and the control groups. The experimental group consists of 16 girls, 16 boys, and the control group consists of 20 girls, 15 boys among secondary school first year students. In the study, quantitative data were collected using metacognitive awareness inventory and reading comprehension test, while qualitative data were collected using semi-structured interview forms. The quantitative part of the study was analyzed using the descriptive statistics method (such as arithmetic mean, correlation analysis, pearson moments multiplication coefficient) and the qualitative part was analyzed using the content analysis method. As a result of the research, a positive relationship was found between metacognitive awareness and reading comprehension.

Research conducted by $\mathrm{Ng}$ [44] explores the effect of using collaborative problem-solving teaching method on metacognitive behavior. Case study method, one of the qualitative research methods, was used in the research. The sample of the study consisted of a total of 617 students in the 7th and 8th grade (13-14 years) studying in 16 branches of three state secondary schools. The data of the research; audiovisual documents were collected through the comments of students and teachers and course observation forms. All the data obtained was gathered and coded, then the data analysis process was completed by reporting. As a result of the research; it was observed that students partially negatively affect each other's metacognitive behavior during the collaborative problem-solving process.

Research by Hong, et al. [45] investigated the effect of a metacognitive plan on students' ability to solve non-routine mathematical problems. Quantitative method was used in the research. The researchers designed their studies as semi-experimental, pretest-posttest, non-equivalent group design. The research sample consists of two study groups, the experimental and the control groups. Experimental group consists of 31 and control group consists of 32 primary school 4th grade students. In the study, the data were collected through questionnaires and pre-test/post-tests. Descriptive statistics methods were used in the analysis of the data. In the study, it was concluded that the use of metacognitive plan has a positive effect on the solution of mathematical problems.

Research by Lee and Teo [46] aimed to understand whether the solution of poorly structured problems used in teacher candidates' education improves the metacognition of prospective teachers, thus obtaining detailed information about prospective teachers' metacognitions. The research was created by quantitative method. The researchers designed their studies as semi-experimental, pretest-posttest, non-equivalent group design. The sample group of the research consists of 294 prospective and graduate teachers. Data were collected through Metacognitive Awareness Inventory. The data obtained in the study were analyzed by using descriptive statistics, factor analysis and MANOVA. In the research, it was concluded that the poorly structured problemsolving activity used in the education of prospective teachers did not cause a big change in the metacognition of the prospective teachers. Researchers think that more research should be done in order to understand the effects of teacher candidates' problem-solving activities on metacognition.

In their study, Kaur and Areepattamannil [47], examined the effects of metacognitive strategies and self-regulating learning strategies on mathematical literacy among adolescents in Australia and Singapore. The research was created by quantitative method. In the study, the Australian sample group consists of 14251 students from 353 schools and the Singapore sample group consists of 5283 students from 171 schools. The data of the research were obtained from the 2009 PISA results. Likert type scale was applied to the sample groups. The data obtained from the research were analyzed using the regression analysis method, which is one of the descriptive statistics techniques. As a result of the research, it was concluded that the use of metacognitive learning strategies and control strategies (such as reading and remembering and summarizing) among adolescents in Australia and Singapore had positive effects on mathematics literacy. On the other hand, 
it was concluded that reading and memorizing strategies, two components of self-regulated learning, had negative effects on the mathematics literacy of adolescents in Australia and Singapore.

\section{RESULTS AND DISCUSSION}

This study tried to reveal how selected research on "metacognition" in Turkey, Japan and Singapore between the years of 2010 and 2020 are related from the point of comparative education. For this purpose, years, countries, research methods and sample working group of the studies has been examined according to comparative education approaches and data collection techniques. In Turkey, quantitative research methods and experimental design were mostly used in research on metacognition. In these researches, the effects of using different teaching methods in education on the metacognitive awareness of students and the relationship between students' level of using metacognitive strategies and reading skills were examined. Also, relationships among metacognition, general intelligence and various variables were presented. Researches were carried out at secondary and university levels. In these studies, it has been identified that metacognitive awareness scale was frequently used.

A study conducted on metacognition in Turkey [34] is about the effects of metacognitive knowledge, metacognitive control and metacognitive monitoring, which are different sub-dimensions of metacognition, on the performance of the learning from texts and general intelligence. According to this research, it was concluded that metacognitive information does not contribute to variability in text learning performance, and metacognitive monitoring and metacognitive control together with general intelligence contributes significantly to variation in text learning performance. In addition, as a result of the same research, it was observed that there was no significant relationship between metacognitive knowledge and metacognitive control and general intelligence, while there was a statistically significant relationship between metacognitive monitoring and general intelligence. In another study on metacognition [1], the effect of web-based teaching on the metacognitive awareness level of students was examined, and as a result of the research, it was determined that web-based teaching did not have a statistically significant effect on students' metacognitive awareness level.

In the research conducted to determine the reading strategies and metacognitive awareness levels of secondary school students and to determine the relationship between the students' reading levels of metacognition and age, gender, reading a book, their grades in Turkish lesson, family reading levels, it was concluded that there is a significant relationship between reading strategies of students and their metacognitive awareness level. No significant difference was found in the study [36] investigating the relationship between metacognition awareness scores and grade levels and gender differences. In the same study, there was no significant difference between the knowledge of cognition and cognition regulation scores. In the study examining the levels of using metacognitive reading strategies from the point of different variables [37], there was no significant difference between the use of pragmatic strategy, which is one of the metacognitive reading strategies and gender. The levels of using analytical strategies from the metacognitive reading strategies were lower than that of male students. In the same study [37], it was concluded that students whose mother education level is "university graduate" and students who graduated from Science High School and Anatolian High School use more metacognitive reading strategies.Researches related to metacognition in Japan showed a balanced distribution among the use of quantitative, qualitative and mixed methods. Research in Japan examined the effects of foreign language (English) learning on metacognitive skills and metacognitive awareness, and the effects of metacognitive regulation and problem solving on critical thinking. The research literature was conducted at primary, secondary and university levels. Semi-structured interview form, observation form and metacognitive awareness scale were used as data collection tools in the studies.

A study on metacognition [38] in Japan has examined the effects of the second language (English) on students' motivational self and metacognitive skills, and it has been concluded that hands on activities has a positive effect on students' metacognitive skills. In another study on metacognition [39], it was concluded that the use of reading strategy in English lessons has no significant effect on students' metacognitive awareness. In a qualitative study [40] on metacognition, it was concluded that there may be different variables related to metacognitive awareness in the individualized foreign language learning process. In a study investigating the effect of metacognitive regulation and problem solving on the development of critical thinking [41], it was estimated that metacognitive regulation and problem-solving process developed critical thinking. In a study examining the effect of individual learning on metacognitive awareness [42], it was concluded that students' learning English individually increases their cognitive and metacognitive awareness.

Metacognition research in Singapore indicated that apart from qualitative and mixed methods quantitative methods were mostly used. In these studies, the relationship between problem solving and metacognition, the relationship between foreign language teaching and mathematics literacy metacognitive strategies were examined. The researches were carried out at primary, secondary, high school and university 
levels. Data related to metacognition were collected by metacognitive awareness scales, questionnaires, observation forms and pre-prepared documents.

Previous study examined the effect of using metacognitive strategy in reading comprehension in Singapore [43], found positive relationship between metacognitive awareness and reading comprehension. In another study [44] examining the effect of using cooperative problem-solving teaching method on metacognitive behaviors, it was found that students partially negatively affected each other's metacognitive behavior during the collaborative problem-solving process. In a study [45] examining the effect of a metacognitive plan on students' ability to solve non-routine mathematical problems, it was found that the use of metacognitive plan had a positive effect in solving mathematical problems. In a research aiming to understand whether solving poorly structured problems used in the education of prospective teachers improves the metacognition of prospective teachers indicated that the poorly structured problem-solving activity used in the training of prospective teachers did not cause a big change in the metacognition of prospective teachers. In a study on adolescents in Australia and Singapore examining the effects of metacognitive strategies and selfregulating learning strategies on mathematical literacy [47] demonstrated that the use of metacognitive learning and control strategies (such as reading and recalling and summarizing) positively affect mathematics literacy. In contrast, reading and memorizing strategies, two components of self-regulated learning, were found to have negative effects on mathematics literacy of adolescents in Australia and Singapore.

In general, the research made about metacognition in Turkey, Japan and Singapore was designed by using quantitative research methods. It has been stated that experimental studies are the main research patterns of the metacognition studies conducted in three countries. Metacognitive awareness scales are the most used data collection tools in all three countries. It is seen that the studies investigating the relationship between students' problem-solving skills and metacognition are in the majority. Researches examining the relationship between metacognition and foreign language teaching and text learning are also among the main research areas.

Mixed research methods can be used on metacognition for future research in Turkey. By this way, it will be possible to obtain more comprehensive data on metacognition. The use of mixed methods allow to more in-depth information to obtain a positive impact on Turkey's ranking in international exams. In addition, conducting research at every educational level will enable generalizations about metacognition. It is seen that most of the studies in Japan include examining the relationship between metacognition and foreign language teaching. Increasing research on other dimensions of metacognition in Japan may allow different perspectives to be developed in terms of metacognition. The number of experimental research on metacognition can be enhanced in Turkey, Japan and Singapore. This will contribute to the development of the theoretical framework related to metacognition. In all three countries, metacognition research involving all education levels, from kindergarten to doctorate level, can be included. For future research, the relationship between students' metacognition and many concepts that affect student's perception can be examined.

\section{CONCLUSION}

When the results of metacognition research conducted in Turkey, Japan, and Singapore were evaluated as a whole, quantitative research methods are seen to be often used by these three countries. However, it has been observed that there is more tendency towards mixed method and qualitative method in Japan. Experimental techniques has been identified as a major research design in Turkey and Singapore. Qualitative research methods have never been used in research conducted in Turkey. This situation reveals the necessity to obtain more in-depth information through qualitative research in this country. Metacognitive awareness scales are the most used data collection tools in all three countries. Studies examining the relationship between students' problem solving skills and metacognition levels are seen to be predominant in Singapore and Japan. Studies which effect metacognition in a positive way like problem solving are needed to be done in Turkey as well. Because problem solving is a method that improves high level learning. On the other hand Turkey based research focuses on reading strategies. Studies that examine the relationship between metacognition and foreign language teaching and textual learning are also among the main research areas.

In research to be done on metacognition in Turkey, more space should be given to the mixed research methods. In this way, it will be possible to obtain more comprehensive data on metacognition. The use of mixed research will allow for more in-depth information to obtain a positive impact on Turkey's achievements in international exams. In addition, conducting the researches to be carried out at every education level will allow generalizations about metacognition. It is seen that studies examining the relationship between metacognition and foreign language teaching in Japan constitute the majority. Increasing research on other dimensions of metacognition in Japan may allow the formation and development of different perspectives on metacognition. The number of experimental researches to be done in Turkey, Japan and Singapore can be increased. This will contribute to the development of the theoretical framework related to metacognition. In all three countries, metacognitive research can be performed covering all learning levels from kindergarten to 
doctoral level. In future studies, the relationship between students' metacognition and many other concepts that affect student perception can be examined. In Turkey, research was mostly conducted to analyze the relationship between metacognition scale and some variables. In addition to these researches, there is a need for qualitative studies such as observation and interview that will examine cognitive processes more closely.

\section{REFERENCES}

[1] M. Baltaci and B. Akpınar, "Web Tabanlı Öğretimin Öğrenenlerin Üstbiliş Farkındalık Düzeyine Etkisi/The Effect of Web Based Instruction On The Metacognition Awareness Levels of Learners," Mustafa Kemal Univ. Sosyal Bilimler Enstitüsü Dergisi, vol. 8, no. 16, pp. 319-333, 2011.

[2] J. H. Flavell, "Metacognitive aspects of problem solving," In L.R. Resnick, Ed., The nature of intelligence. Hillsdale, NJ: Lawrence Erbaum, 1976.

[3] J. H. Flavell, "Metacognitive and Cognitive Monitoring: A New Area of Cognitive Developmental Inquiry," American Psychologyst, vol. 34, no. 10, pp. 906-911, 1979, doi: 10.1037/0003-066X.34.10.906.

[4] A. L. Brown, "Metacognition, executive control, self-regulation, and other more mysterious mechanisms," In F. E. Weinert, R. H. Kluwe, Eds., Metacognition, motivation, and understanding. Hillsdale, NJ: Erlbaum, 1987, pp. 65-116, doi: 10.1037/0003-066X.34.10.906.

[5] T. O. Nelson, “Cognition versus metacognition,” In R. J. Sternberg, Ed., The nature of cognition. Cambridge, MA: MIT Press, pp. 625-641, 1999.

[6] G. Schraw and R. S. Dennison, "Assessing metacognitive awareness," Contemporary Educational Psychology, vol. 19, pp. 460-475, 1994, doi: 10.1006/ceps.1994.1033.

[7] J. H. Flavell, "Speculations about the nature and development of metacognition," In F. E. Weinert and R. H. Kluwe, Eds., Metacognition, motivation and understanding. Hillsdale, NJ: Erlbaum, 1987, pp. 21-29.

[8] W. Pierce, "Metacognition: Study Strategies, Monitoring, and Motivation," presented at Prince George's Community College, 2004. [Online]. Available: http://academic.pgcc.edu/ wpeirce/MCCCTR/metacognition.htm.

[9] D. H. Schunk, "Metacognition, Self-Regulation, and Self-Regulated Learning: Research Recommendations," Educational Psychology Review, vol. 20, pp. 463-467, 2008.

[10] C. A. R. Leonard, "Quality of School Life and Attendance in Primary Schools," Unpublished PhD Thesis, Newcastle Üniversitesi, Newcastle, 2002.

[11] G. Özsoy and A. Ataman, "The effect of metacognitive strategy training on mathematical problem solving achievement," International Electronic Journal of Elementary Education, vol. 1, pp. 67-82, 2009.

[12] B. Kaur and L. F. Wong, "A collaborative and reflective approach to teaching for metacognition," Paper presented at the Annual Meeting of the Mathematics Education Research Group of Australasia (MERGA), Adelaide, South Australia, 2016. [Online]. Available: https://eric.ed.gov/?id=ED572373.

[13] A. Memiş and H. Arıcan, "Beşinci sınıf öğrencilerinin matematiksel üstbiliş düzeylerinin cinsiyet ve başarı değişkenleri açısından incelenmesi," Karaelmas Eğitim Bilimleri Dergisi, vol. 1, no. 1, pp. 76-93, 2013.

[14] C.C.M. Goh and K. Kaur, "Insights into young learners' metacognitive awareness about listening," European Journal of Applied Linguistics and TEFL, vol. 2, pp. 5-26, 2013.

[15] Ç. N. Hıdıroğlu and E. B. Güzel, "Teknoloji Destekli Ortamda Matematiksel Modellemede Ortaya Çıkan Üst Bilişsel Yapılar," Turkish Journal of Computer and Mathematics Education, vol. 6, no. 2, pp. 179-208, 2015, do1: 10.16949/turcomat.00708.

[16] Ç. N. Hıdıroğlu and E. B. Güzel, "Transitions between Cognitive and Metacognitive Activities in Mathematical Modelling Process within a Technology Enhanced Environment," Necatibey Faculty of Education Electronic Journal of Science \& Mathematics Education, vol. 10, no. 1, pp. 313-350, 2016.

[17] Ç. N. Hıdıroğlu and Y. Ö. Hıdıroğlu, "Modelleme Yaklaşımlarına Bütüncül Bir Bakış ve Yeni Bir Öğrenme Modeli Önerisi: HTTM Modeli ve Kuramsal Temeli,” in Ö. Demirel ve S. Dinçer, eds., Eğitim Bilimlerinde Yenilik ve Nitelik Arayışı. Ankara: Pegem Akademi, 2016, pp. 1099-1132.

[18] Ç. Hıdıroğlu, "Üstbiliş Kavramına ve Problem Çözme Sürecinde Üstbilişin Rolüne Eleştirel Bir Bakış," Pamukkale Üniversitesi Sosyal Bilimler Enstitüsü Dergisi, no. 32, pp. 87-103, 2018, do1: 10.30794/pausbed.424862.

[19] M. A. Raihan, “'Think-aloud' techniques used in metacognition to enhance self-regulated learning," Journal of Educational Research, vol. 25, no. 2, pp. 125-160, 2011.

[20] M. Mok and M. Flynn, "Determinants of students' quality of school life: A path model," Learning Environment Research, vol. 5, pp. 275-300, 2002, doi: 10.1023/A:1021924322950.

[21] A. Türkoğlu, Fransa, İsveç ve Romanya Eğitim Sistemleri. Ankara: Ankara Üniversitesi Eğitim Bilimleri Fakültesi Basımevi, 1985.

[22] S. Kuruçetin, S. Korkmaz, and N. Öner, "Karşılaştırmalı Eğitim Alanında 15 Yılda Yapılan Çalışmaların Farklı Değişkenler Açısından İncelenmesi," Adnan Menderes Üniversitesi Eğitim Fakültesi Eğitim Bilimleri Dergisi, vol. 8, no. 2, pp. 28-40, 2017.

[23] P. G. Altbach and G. P. Kelly, New Approach to Comparative Education. Chicago: University of Chicago, 1986.

[24] G. Özsoy, "Üstbiliş," Türk Eğitim Bilimleri Dergisi, vol. 6, no. 4, pp. 713-740, 2008.

[25] PİSA, "PISA Country Profiles," 2018. [Online]. Available: https://www.oecd.org/pisa. (accessed Apr. 25, 2018)

[26] M. Bray and R. M. Thomas, "Levels of comparison in educational studies: different insights from different literatures and the value of multilevel analysis," Harvard Educational Review, vol. 65, no. 3, pp. 472-489, 1995, doi: 10.17763/haer.65.3.g3228437224v4877.

[27] İ. Yüksel and M. Sağlam, Karşılaştırmalı eğitim yansımaları. Ankara :Pegem Akademi, 2012. 
[28] A. Yıldırım and H. ve Şimşek, Sosyal bilimlerde nitel araştırma yöntemleri. Ankara: Seçkin Yayıncıllk, 2018.

[29] D. D. Minner, A. J. Levy, and J. Century, "Inquiry-based science instruction-what is it and does it matter? Results from a research synthesis years 1984 to 2002," Journal of Research in Science Teaching, vol. 47, pp. 474-496, 2010, doi: 10.1002/tea.20347.

[30] H. Suri and D. Clarke, "Advancements in research synthesis methods: from a methodologically inclusive perspective," Review of Educational Research, vol. 79, no. 1, pp. 395-430, 2009, doi: 10.3102/0034654308326349.

[31] N. Karasar, Bilimsel Araştırma Yöntemleri. Ankara: Nobel Yayıncılık, 2019.

[32] A. Erkuş, Davranış Bilimleri için Bilimsel Araştırma Süreci. Ankara: Seçkin Yayıncılık, 2009.

[33] Z. Karaçam, "Sistematik Derleme Metodolojisi: Sistematik Derleme Hazırlamak İçin Bir Rehber," Dokuz Eylül Üniversitesi Hemşirelik Yüksekokulu Elektronik Dergisi, vol. 6, no. 1, pp. 26-33, 2013.

[34] S. Saraç, A. Önder, and S. Karakelle, "Üstbiliş, Zeka Ve Metinden Öğrenme Performansı Arasindaki Ilişkiler," Egitim ve Bilim, vol. 39, no. 173, pp. 40-53, 2014.

[35] F. Kana, "Metacognitive Awareness of Reading Strategies Levels of Secondary School Students," Erzincan Üniversitesi Ĕ̈itim Fakültesi Dergisi, vol. 16, no. 1, pp. 100-120, 2014, doi: 10.17556/jef.73171.

[36] D. Deniz, B. Küçük, Ş. Cansız, L. Akgün, and T. İşleyen, "Ortaöğretim Matematik Öğretmeni Adaylarının Üstbiliş Farkındalıklarının Bazı Değişkenler Açısından İncelenmesi,” Kastamonu Ĕ̆itim Dergisi, vol. 22, no. 1, pp. 305-320, 2014.

[37] M. Gökşen, "İngilizce Öğretmeni Adaylarının Üst Bilişsel Okuma Stratejilerini Kullanma Düzeylerinin Farklı Değişkenler Açısından İncelenmesi (Erciyes Üniversitesi Örneği),” Master Thesis, 2019.

[38] L. Adrian, "The Effects of a Study Abroad Experience on the L2 Motivational Self and Metacognitive Skills: A study of a junior highschool trip abroad," Bulletin of Miyagi University of Education, 2014. [Online]. Available: http://id.nii.ac.jp/1138/00000267.

[39] M. Shikano, "A Quantitative Survey on Metacognitive Awareness of Reading Strategy Use in English by Japanese University Students," pp. 11-24, 2013.

[40] J. Mynard, "Promoting Cognitive and Metacognitive Awareness Through Self-Study Modules: An Investigation into Advisor Comments," 2010.

[41] Y. Gotoh, "Development of Critical Thinking with Metacognitive Regulation," 13th International Conference on Cognition and Exploratory Learning in Digital Age (CELDA 2016), 2016, pp. 353-356.

[42] R. J. Werner and Y. Kobayashi, "Self-Access and Metacognitive Awareness in Young Learners: How Japanese Sixth Graders Learn How to Learn English,” Studies in Self-Access Learning Journal, vol. 6, no. 4, pp. 399-412, 2015, doi: $10.37237 / 060406$.

[43] C. Dabarera, W. A. Renandya, and L. J. Zhang, "The impact of metacognitive scaffolding and monitoring on reading comprehension," System, vol. 42, no. 1, pp. 462-473, 2014, doi: 10.1016/j.system.2013.12.020.

[44] K. E. D. Ng, "Partial Metacognitive Blindness in Collaborative Problem Solving," Proceedings of the 33rd Annual Conference of the Mathematics Eduation Research Group of Australasia, 2010, pp. 446-453.

[45] S. E. Hong, N. H. Lee, and D. J. Yeo, "A metacognitive approach in kick-starting the understanding and planning phases of mathematical problem solving," 12th International Congress on Mathematical Education (ICME-12), 2012, pp. 4450-4458. [Online]. Available: http://hdl.handle.net/10497/15916.

[46] C. B. Lee and T. Teo, "Shifting pre-service teachers' metacognition through problem solving," Asia-Pacific Education Researcher, vol. 20, no. 3, pp. 570-578, 2011.

[47] B. Kaur and S. Areepattamannil, "Influences of Metacognitive and Self-Regulated Learning Strategies for Reading on Mathematical Literacy of Adolescents in Australia and Singapore," Mathematics Education Research Group of Australasia, July, pp. 2-6, 2012.

[48] R. A. Sperling, B. C. Howard, L. A. Miller, and C. Murphy, "Measures of children's knowledge and regulation of cognition," Contemporary Educational Psychology, vol. 27, pp. 51-79, 2002, doi: 10.1006/ceps.2001.1091.

[49] G. Schraw and R. S. Dennison, "Effects of task-driven interest on recall of text," Journal of Reading Behavior, vol. 26, pp. 1-18, 1994.

[50] E. Öztürk, "Okuma Stratejileri Üstbilişsel Farkındalık Envante-ri’nin Türkçe Formunun Geçerlik ve Güvenirlik Çalışması," Ill-kögretim Online, vol. 11, no. 2, pp. 292-305, 2012, doi: 10.17051/IO.2976.

[51] R. Taraban, M. Kerr, and K. ve Rynearson, "Analytic and pragmatic factors in college students' metacognitive reading strategies," Reading Psychology, vol. 25, pp. 67-81, 2004, doi: 10.1080/02702710490435547.

[52] S. Çöğmen, "Eğitim fakültesi öğrencilerinin kullandıkları okuduğunu anlama stratejileri," Yayımlanmamış Yüksek Lisans Tezi, Adnan Menderes Üniversitesi Sosyal Bilimler Enstitüsü, Aydın, 2008 